\title{
Structural and Chemical Profiles of Myrcia splendens (Myrtaceae) Leaves Under the Influence of the Galling Nexothrips sp. (Thysanoptera)
}

\section{OPEN ACCESS}

Edited by:

Raul Antonio Sperotto,

University of Taquari Valley, Brazil

Reviewed by:

Robert Malinowski,

Institute of Plant Genetics (PAN),

Poland

Jorge Vicente,

University of Nottingham,

United Kingdom

*Correspondence:

Rosy Mary Santos Isaias

rosy@icb.ufmg.br

Specialty section:

This article was submitted to

Plant Microbe Interactions,

a section of the journal

Frontiers in Plant Science

Received: 30 May 2018

Accepted: 27 September 2018

Published: 06 November 2018

Citation:

Jorge NC, Souza-Silva ÉA,

Alvarenga $D R$, Saboia G,

Soares GLG, Zini CA, Cavalleri A and

Isaias RMS (2018) Structural

and Chemical Profiles of Myrcia splendens (Myrtaceae) Leaves Under the Influence of the Galling Nexothrips

sp. (Thysanoptera).

Front. Plant Sci. 9:1521. doi: 10.3389/fpls.2018.01521

\begin{abstract}
Nina Castro Jorge ${ }^{1}$, Érica A. Souza-Silva $a^{2,3}$, Danielle Ramos Alvarenga ${ }^{1}$, Giovanni Saboia ${ }^{3}$, Geraldo Luiz Gonçalves Soares4, Cláudia Alcaraz Zini3, Adriano Cavalleri ${ }^{5}$ and Rosy Mary Santos Isaias ${ }^{1 *}$
\end{abstract}

\begin{abstract}
'Laboratório de Anatomia Vegetal, Departamento de Botânica, Instituto de Ciências Biológicas, Universidade Federal de Minas Gerais, Belo Horizonte, Brazil, ${ }^{2}$ Departamento de Química, Instituto de Ciências Ambientais, Químicas e Farmacêuticas, Universidade Federal de São Paulo, UNIFESP, Diadema, Brazil, ${ }^{3}$ Laboratório de Química Analítica Ambiental e Oleoquímica, Departamento de Química Inorgânica, Instituto de Química, Universidade Federal do Rio Grande do Sul, Porto Alegre, Brazil, ${ }^{4}$ Laboratório de Ecologia Química e Quimiotaxonomia, Departamento de Botânica, Instituto de Biociências, Universidade Federal do Rio Grande do Sul, Porto Alegre, Brazil, ${ }^{5}$ Instituto de Ciências Biológicas, Universidade Federal do Rio Grande, São Lourenço do Sul, Brazil
\end{abstract}

Thysanoptera-induced galls commonly culminate in simple folding or rolling leaf gall morphotypes. Most of these galls are induced by members of the suborder Tubulifera, with only a few species of the suborder Terebrantia being reported as gall inducers. The Terebrantia, as most of the gall inducers, manipulates the host plant cellular communication system, and induces anatomical and biochemical changes in its host plant. In an effort to keep its homeostasis, the host plant reacts to the stimuli of the galling insect and triggers chemical signaling processes. In contrast to free-living herbivores, the signaling processes involving galling herbivores and their host plants are practically unknown. Current investigation was performed into two steps: first, we set the structural profile of non-galled and galled leaves, and looked forward to find potential alterations due to gall induction by an undescribed species of Nexothrips (suborder Terebrantia) on Myrcia splendens. Once oil glands had been altered in size and number, the second step was the investigation of the chemical profile of three tissue samples: (1) non-galled leaves of a control individual, (2) non-galled leaves of galled plants, and (3) galls. This third sample was divided into two groups: (3.1) galls from which the inducing thrips were manually removed and (3.2) galls macerated with the inducing thrips inside. The chemical profile was performed by gas chromatography/ mass spectrometric detector after headspace solid-phase extraction. The galling activity of the Nexothrips sp. on $M$. splendens culminates in mesophyll compactness interspersed to diminutive hypersensitive spots, development of air cavities, and the increase in size and number of the secretory glands. Seventy-two compounds were completely identified in the volatile profile of the three samples, from which, sesquiterpenes and aldehydes, pertaining to the "green leaf volatile" (GLVs) class, are the most abundant. The rare event of gall induction by a Terebrantia revealed discrete alterations toward leaf rolling, and indicated 
quantitative differences related to the plant bioactivity manipulated by the galling thrips. Also, the content of methyl salicylate has varied and has been considered a potential biomarker of plant resistance stimulated as a long-distance effect on $M$. splendens individuals.

Keywords: methyl salicylate, Myrcia-thrips system, plant-insect interactions, rolling galls, volatiles

\section{INTRODUCTION}

Among the galling insects, Thysanoptera, commonly known as thrips, are suckers and induce their galls (Meyer, 1987) by means of chemical and/or mechanical stimuli, and alter the development of their host plant tissues (Mani, 1964; Hori, 1992). Galls result from the interaction between a galling organism and its host plant, and demand a high complex and intimate interaction between the associated species (Shorthouse et al., 2005; Raman, 2007). The galling organism manipulates the cellular communication system of the host plant by suppressing its defenses (Oates et al., 2016), and induces anatomical and biochemical changes in the host plant (Raman et al., 2005). Previous studies show that galling insects manipulate plant cells and tissues by the interaction between secondary metabolism and phytohormones (Bedetti et al., 2014). Also, gall induction impairs redox homeostasis, and the accumulation of reactive oxygen species in cell walls is responsible for cell wall loosening and consequent cell redifferentiation and hypertrophy (Isaias et al., 2015). Both of these processes are commonly observed during gall growth and development. Nevertheless, how the insect is able to achieve such an extraordinary level of control over its host plant is perhaps the most intriguing question surrounding plant-galling insect interaction (Oates et al., 2016), and has not been fully described yet.

Along the process of gall induction and the establishment of the galling organism within plant tissues, the plant reacts to the presence of the parasite and chemical signaling mechanisms initiate. Such phenomenon of chemical signaling on plant-herbivore interactions has been widely explored for free-living insects (Rosenthal and Berenbaum, 1992; Dicke et al., 1993), but the signaling mediated by volatile secondary metabolites between galling insects and their host plants is practically unknown (Damasceno et al., 2010).

Gall induction may stimulate the neo-synthesis of secondary metabolites (Oliveira et al., 2006; Guedes et al., 2016) or the standard synthesis of both primary and secondary metabolites may be maintained, but their accumulation is translocated to specific gall tissue compartments (Carneiro et al., 2014; Bragança et al., 2017). Host plants with high potential for the production of volatiles, such as Myrcia splendens (Myrtaceae), may come up with novelties regarding the chemical profile of primary metabolites and their involvement in biotic association. The volatile content of the oil glands of $M$. splendens leaves has $95 \%$ of sesquiterpenes (Cole et al., 2008; Nakamura et al., 2010), mostly composed of hydrocarbons and oxygenated sesquiterpenes

Abbreviations: CLRG, clean-leaf rolling galls, where cLRG stands for clean leaf galls; Ctrl, control individual; LRGwT, leaf rolling galls without thrips, where " $\mathrm{wT}$ " stands for "with thrips"; NGL, non-galled leaves.
(Cole et al., 2008), this volatile profile can be altered after gall induction.

Our study focuses on a rolling gall morphotype induced by a tiny Thripinae, an undescribed species of Nexothrips (suborder Terebrantia) on M. splendens (Sw) DC, and it aimed to (1) characterize gall anatomical structure to elucidate how the host plant cell an tissue responses lead to the rolling of leaf lamina; (2) quantify the number and area of the essential oil-producing glands in order to determine whether the gall induction alters the host leaf potential for the production of volatiles; and (3) trace the composition of the volatile compounds emitted by non-galled leaves of a plant totally free of galls (the control individual), by non-galled leaves of galled plants, and by Nexothrips sp. galls to detect possible biomarkers of the biotic stress related to gall induction and establishment.

\section{MATERIALS AND METHODS}

Non-galled leaves and rolling galls were collected from a population of M. splendens (Sw.) DC. in Serra Verde State Park (Parque Estadual Serra Verde, PESV), Belo Horizonte, Minas Gerais, Brazil $\left(19^{\circ} 47^{\prime} 21.8^{\prime \prime} \mathrm{S} 43^{\circ} 57^{\prime} 34.4^{\prime \prime} \mathrm{W}\right)$. The characterization of the gall morphotype followed Isaias et al. (2013). Individuals of M. splendens $(n=20)$ were tagged, and monitored monthly from February 2015 to March 2016. The gall cycle and the diagnosis of the galled and non-galled condition of the individuals, as well as the occurrence and frequency of the galls were analyzed.

\section{Anatomical Analysis}

For anatomical observations, non-galled leaves and mature rolling galls $(n \geq 5)$ were fixed in FAA (formalin, acetic acid, 50\% ethanol, 1:1:18) (Johansen, 1940), dehydrated in an $n$-buthanolic series and embedded in Paraplast ${ }^{\circledR}$ (Kraus and Arduin, 1997). The material was sectioned $(12 \mu \mathrm{m})$ in a rotatory microtome (Leica 2035 BIOCUT $^{\circledR}$ ), deparaffinized, and stained in astra blue-safranin 9:1 (v/v) (Bukatsch, 1972, modified to 0.5\%). The slides were mounted with varnish Acrilex ${ }^{\circledR}$ (Paiva et al., 2006), and the images were obtained with a photomicroscope (Leica ICC50 $\left.\mathrm{HP}^{\circledast}\right)$.

\section{Scanning Electron Microscopy (SEM)}

Non-galled leaves and rolling galls fixed in FAA (Johansen, 1940) were dehydrated in an ethanolic series (Johansen, 1940), critical point dried, mounted on stubs, and covered with $15 \mathrm{~nm}$ of gold (Balzers SCD 050) (O'Brien and McCully, 1981). The samples were observed in a scanning electron microscope (JEOL JSM - 6360LV) in the Center of Microscopy at the Universidade 

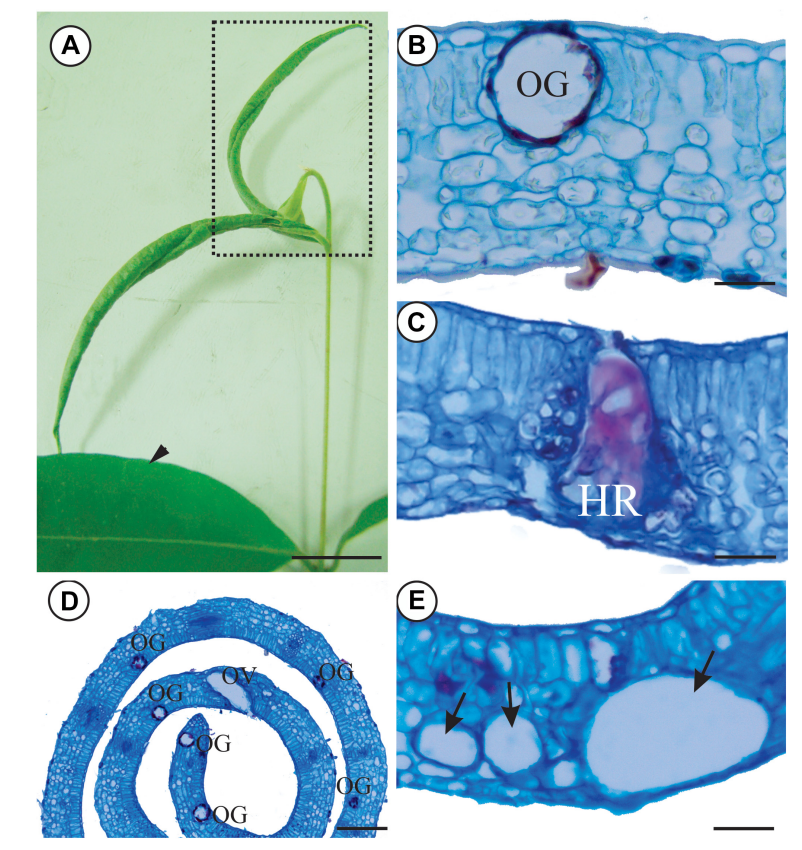

FIGURE 1 | Non-galled leaves and galls induced on leaves of Myrcia splendens by an undescribed species of Nexothrips (suborder Terebrantia) (A) Non-galled leaves and stem branch with leaf rolling galls. (B) Anatomy of non-galled leaves, evidencing the mesophyll and oil glands. (C) Gall mesophyll, evidencing the hypersensitive reaction in response to the inducer's feeding activity. (D) Anatomy of a gall, evidencing the increased number of secretory cavities. (E) Gall mesophyll, evidencing the reduction of intercellular spaces and air cavities. Arrowhead: Non-galled leaves, Dashed: Rolling gall, OG: Oil gland, OV: Oviposition, HR: Hypersensitive area, Arrow: Air cavities Scale bars: A: $2 \mathrm{~cm}, \mathbf{B}, \mathbf{C}, \mathbf{E}: 50 \mu \mathrm{m}$; D: $200 \mu \mathrm{m}$.

Federal de Minas Gerais, Belo Horizonte, Minas Gerais state, Brazil ${ }^{1}$.

\section{Quantitative Analysis of Glands}

For the analysis of oil glands, non-galled leaves (NGL) and mature rolling galls ( $n=20$ per sample) were clarified in $50 \%$ potassium hydroxide until complete bleaching, washed in water (three times), stained with 1\% safranin in 95\% ethanol, and dehydrated in ethanolic series (Bersier and Bocquet, 1960). The slides were mounted with varnish Acrilex $^{\circledR}$ (Paiva et al., 2006), and the images were obtained with a photomicroscope (Leica ICC50 $\left.\mathrm{HP}^{\circledR}\right)$. The number of glands per area $\left(8.00 / \mathrm{mm}^{2}\right)$ was counted, and the relative area of the glands on non-galled leaves and rolling galls was measured using the AxioVision 7.4 software (Carl Zeiss ${ }^{\circledR}$ Microscopy GmbH, Jena, Germany). Statistical analyzes were performed using the SigmaStat ${ }^{\circledR}$ software, and $t$-test was applied considering $p \leq 0.05$.

\section{Profile of Volatile Compounds by HS-SPME-GC/MS}

Volatile compounds were analyzed in (1) non-galled leaves $(n=5)$ from an individual $(n=1)$, which did not have galls along

${ }^{1}$ http://www.microscopia.ufmg.br the year (the control individual), and (2) non-galled leaves $(n=5)$, and (3) leaf rolling galls $(n=5)$ from young individuals $(n=14)$ of M. splendens in vegetative phenophase in July 2016. The samples were collected and immediately placed under dry ice, in the field. They were macerated in liquid nitrogen, powdered, and divided into 3 to 5 vials of $20 \mathrm{ml}$ ( $25 \mathrm{mg} / \mathrm{vial})$, in the laboratory. The vials were immediately stored in ultrafreezer $\left(-80^{\circ} \mathrm{C}\right)$ until analysis.

The samples were divided into four composites, as follows: (1) control individual (Ctrl) - composite of all leaves obtained from the non-galled individual; (2) non-galled leaves (NGL) composite of the leaves of the fourteen individuals; and (3) leaf-rolling galls - composite of the galls of the fourteen individuals, divided into two groups: (3.1) galls from which the inducing thrips were manually removed (cLRG), for the detection of volatiles exclusive to plant tissues, and (3.2) galls macerated with the inducing thrips inside (LRGwT) for detection of volatile compounds exclusive to the inducing thrips.

Volatile profiles were obtained by extracting the compounds from the samples employing HS-SPME with subsequent analyses by gas chromatography coupled to mass spectrometry (Souza Silva et al., 2017). Briefly, $20 \mathrm{~mL}$ vial containing $0.025 \mathrm{~g}$ of powdered plant material was taken from the ultrafreezer just before extraction. Immediately, $2 \mu \mathrm{L}$ of internal standard (aqueous solution of 1,4-cineole at $100 \mathrm{ng} \mu \mathrm{L}^{-1}$ ) was added to the sample with the use of a $10 \mu \mathrm{L}$ Hamilton syringe pierced through the vial cap septum, without opening the vial cap. Subsequently, each sample vial was pre-incubated on a home-made heating block at $30 \pm 2{ }^{\circ} \mathrm{C}$, without agitation, for $30 \mathrm{~min}$ prior to exposure of the SPME fiber to the vial HS. After 15 min of extraction, the fiber was desorbed into the GC injector at $240{ }^{\circ} \mathrm{C}$ for $15 \mathrm{~min}$. Upon desorption of the volatile compounds, the samples were analyzed by gas chromatography coupled to mass spectrometry (GC/MS) with a Shimadzu 2010Q-Plus GC/MS equipment equipped with a DB-5 column $(30 \mathrm{~m} \times 0.25 \mathrm{~mm} \times 0.25 \mu \mathrm{m})$.

Peaks in the total ion current chromatograms (TICC) were tentatively identified comparing the experimentally acquired mass spectra and the NIST08 mass spectral library, with minimal mass spectra match threshold of $80 \%$. In addition, retention indices (RI) were determined using data obtained from an $n$-alkane solution (C8-C28), and compared to RI reported in the literature. For sesquiterpenes, whenever an appropriate match between mass spectra library hit and retention index was not found, only the family group was designated, according to their mass spectra fragmentation. Relative amounts, as percentages of each component, were achieved by peak area normalization measured without any correction factor. The response obtained for the internal standard 1,4-cineole, measured as area counts, was utilized to monitor possible drifts in instrumental response (Adams, 2001, 2007; Supplementary Material).

The final data matrix containing the relative percentages of each identified peak was submitted to statistical analysis. All analyses were performed assuming 95\% level of confidence ( $\alpha=0.05)$. Since the chromatographic response (area) for each compound had already been normalized, no further data normalization or transformation was performed, and scaling of the data was performed using Pareto scaling (mean-centered and divided by the square root of standard deviation of each 

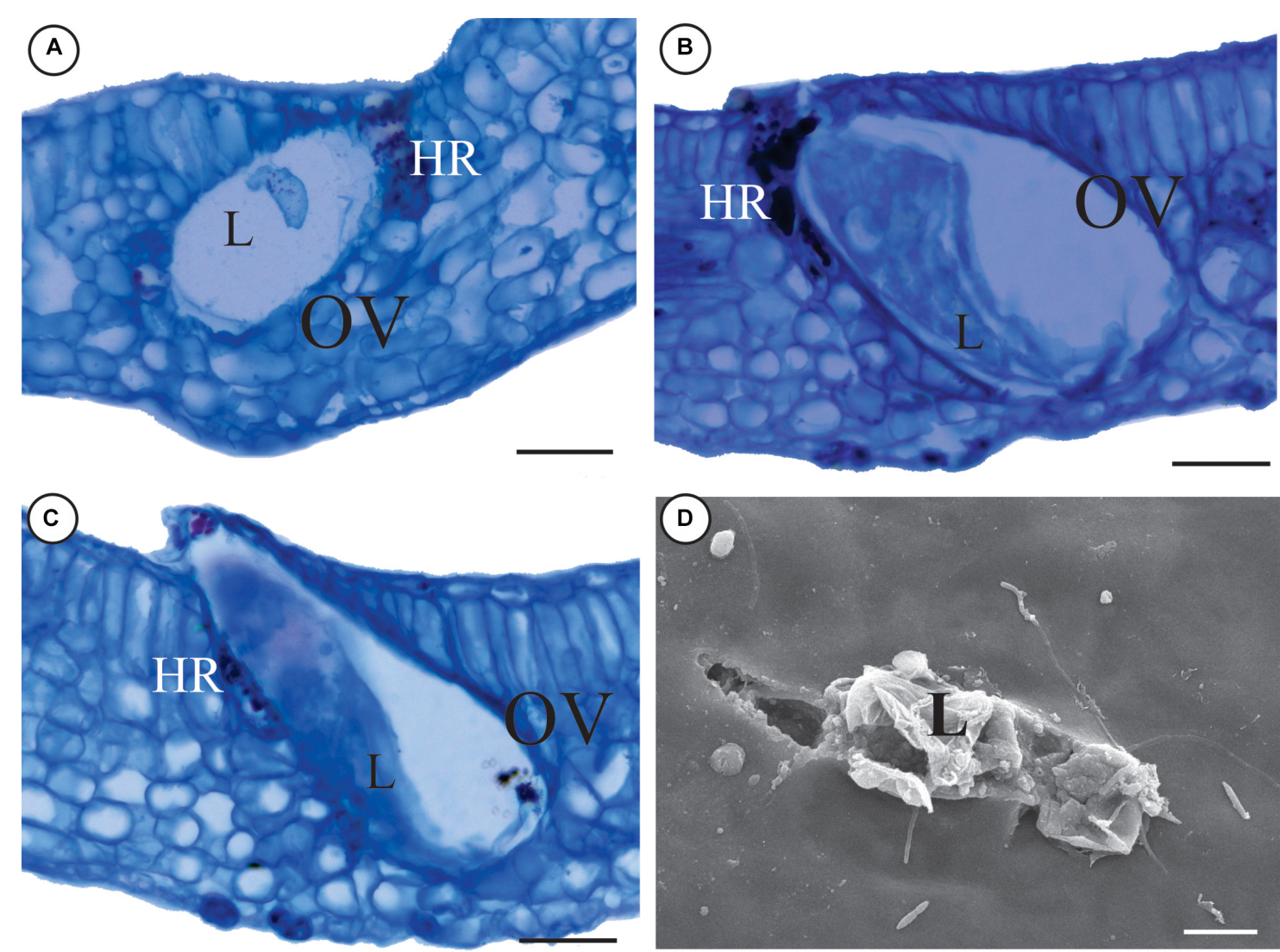

FIGURE 2 | Oviposition inside the tissues of a M. splendens rolling gall induced by an undescribed species of Nexothrips (suborder Terebrantia). (A) Initial development of the larva inside gall tissues. (B) Development of the larva. (C,D) Larvae hatching out of gall tissues. (C) Anatomy of a gall, evidencing hatching out of the leaf tissue. (D) MEV slides evidencing the hatching. L: Larva, OV: oviposition, HR: Hypersensitive area. Scale bars: A-C: $50 \mu m$; D: $10 \mu m$.

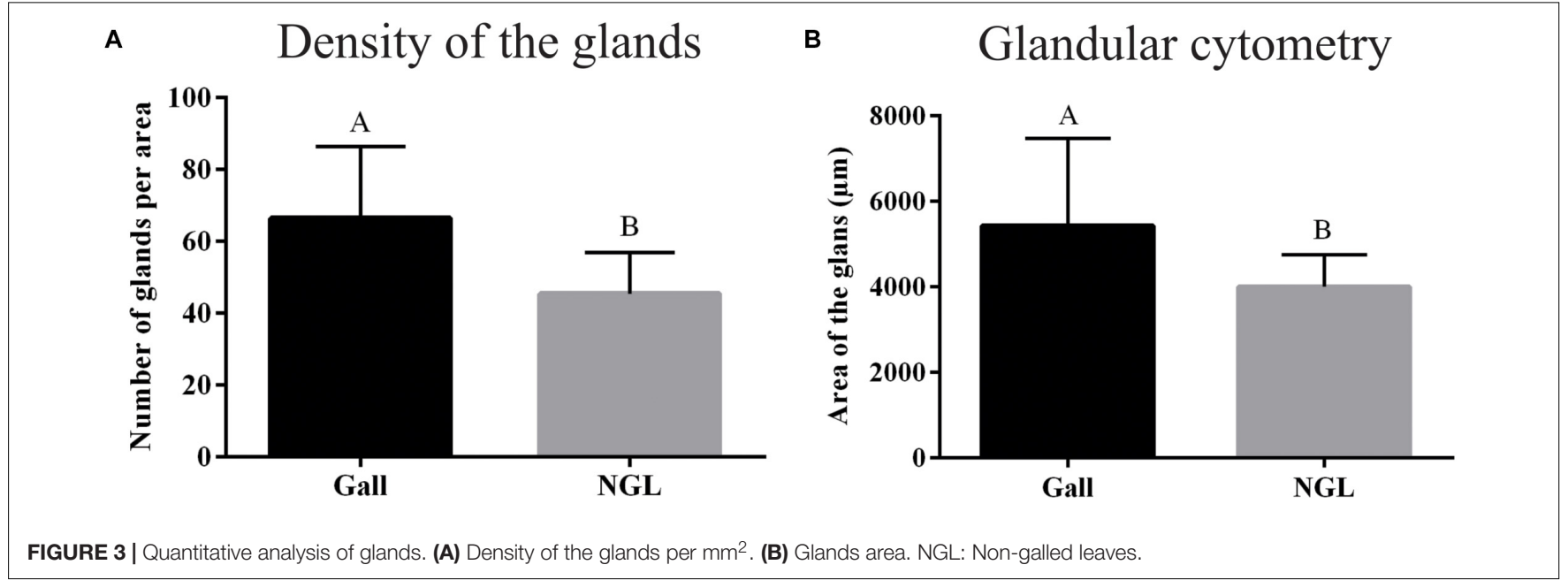

variable) in order to give all variables equal weight regardless their absolute value. This procedure is especially useful to generate a sound statistical analysis since the levels of the volatile compounds found may be of very different orders of magnitude. After data pre-processing, Principal Component Analysis (PCA), heat map with hierarchical clustering, and Partial Least Squares
Discriminant Analysis (PLS-DA) were performed using webbased metabolomic data processing tool MetaboAnalyst ${ }^{2}$. PCA was used to detect intrinsic clusters and outliers within the data set, while PLS-DA maximized class discrimination.

${ }^{2}$ http://www.metaboanalyst.ca 
TABLE 1 | Metabolites tentatively and positively identified in the headspace of galled and non-galled leaves of Myrcia splendens.

\begin{tabular}{|c|c|c|c|c|c|}
\hline$\#$ & Analyte & Class & RT (min) & $\mathbf{R} \mathbf{I}_{\text {exp }}$ & $\mathbf{R} \mathbf{I}_{\text {Lit }}$ \\
\hline 1 & Ethanol & Alcohol & 1.864 & 636 & 448 \\
\hline 2 & 1-Penten-3-ol & Alcohol (GLV) & 3.894 & 690 & 684 \\
\hline 3 & 1-Penten-3-one & Ketone (GLV) & 3.945 & 691 & 686 \\
\hline 4 & Pentanal & Aldehyde (GLV) & 4.203 & 698 & 699 \\
\hline 5 & 3-Buten-1-ol, 3-methyl- & Alcohol (GLV) & 5.201 & 724 & 724 \\
\hline 6 & 1-Butanol, 3-methyl- & Alcohol (GLV) & 5.432 & 730 & 733 \\
\hline 7 & 3-Penten-2-one & Ketone (GLV) & 5.525 & 733 & 733 \\
\hline 8 & 2-Pentenal, (E)- & Aldehyde (GLV) & 5.666 & 737 & 740 \\
\hline 9 & 2-Pentenal, (Z)- & Aldehyde (GLV) & 6.017 & 746 & 740 \\
\hline 10 & 1-Pentanol & Alcohol (GLV) & 6.715 & 763 & 763 \\
\hline 11 & 2-Penten-1-ol, (Z)- & Alcohol (GLV) & 6.819 & 767 & 767 \\
\hline 12 & 3-Hexenal, (Z)- & Aldehyde (GLV) & 7.958 & 797 & 796 \\
\hline 13 & Hexanal & Aldehyde (GLV) & 8.02 & 799 & 800 \\
\hline 14 & 2-Hexenal, (E)- & Aldehyde (GLV) & 10.968 & 855 & 854 \\
\hline 15 & 3-Hexen-1-ol, (Z)- & Alcohol (GLV) & 11.114 & 858 & 857 \\
\hline 16 & 2-Hexen-1-ol, (E)- & Alcohol (GLV) & 11.597 & 866 & 863 \\
\hline 17 & 1-Hexanol & Alcohol (GLV) & 11.718 & 869 & 871 \\
\hline 18 & Heptanal & Aldehyde (GLV) & 13.317 & 899 & 901 \\
\hline 19 & $\alpha$-Thujene & Monoterpene & 14.786 & 925 & 924 \\
\hline 20 & $\alpha$-Pinene & Monoterpene & 15.106 & 931 & 934 \\
\hline 21 & Benzaldehyde & Aromatic & 16.362 & 952 & 960 \\
\hline 22 & 4-Hexen-3-one, 5-methyl- & Ketone & 16.499 & 955 & 961 \\
\hline 23 & $\beta$-Pinene & Monoterpene & 17.491 & 972 & 974 \\
\hline 24 & 1-Octen-3-one & Ketone & 17.657 & 975 & 975 \\
\hline 25 & 1-Octen-3-ol & Alcohol & 17.827 & 978 & 980 \\
\hline 26 & 5-Hepten-2-one, 6-methyl- & Ketone & 18.177 & 984 & 985 \\
\hline 27 & 2,4-Heptadienal, (E,E)- & Aldehyde & 18.613 & 992 & 1011 \\
\hline 28 & D-Limonene & Monoterpene & 20.48 & 1026 & 1027 \\
\hline 29 & Benzyl Alcohol & Aromatic & 20.696 & 1030 & 1032 \\
\hline 30 & Benzeneacetaldehyde & Aromatic & 21.104 & 1037 & 1040 \\
\hline 31 & $\beta$-Ocimene & Monoterpene & 21.676 & 1047 & 1050 \\
\hline 32 & Linalool oxide & Monoterpene & 22.911 & 1070 & 1069 \\
\hline 33 & $\alpha$-Terpinolene & Monoterpene & 23.783 & 1086 & 1088 \\
\hline 34 & Linalool & Monoterpene & 24.431 & 1097 & 1097 \\
\hline 35 & Nonanal & Aldehyde & 24.648 & 1101 & 1101 \\
\hline 36 & Phenylethyl Alcohol & Aromatic & 24.65 & 1108 & 1106 \\
\hline 37 & cis-Pinocarveol & Monoterpene & 26.384 & 1135 & 1136 \\
\hline 38 & 2,4,6-Octatriene, 2,6-dimethyl-, (E,Z)- & Monoterpene & 26.663 & 1128 & 1131 \\
\hline 39 & $\alpha$-Terpinen-4-ol & Monoterpene & 28.432 & 1174 & 1178 \\
\hline 40 & Naphthalene & Aromatic & 28.551 & 1176 & 1169 \\
\hline 41 & Butanoic acid, 3-hexenyl ester, (Z)- & Ester & 28.999 & 1185 & 1184 \\
\hline 42 & Methyl salicylate & Ester & 29.234 & 1190 & 1193 \\
\hline 43 & Octanoic acid, ethyl ester & Ester & 29.585 & 1193 & 1195 \\
\hline 44 & Decanal & Aldehyde & 29.928 & 1203 & 1205 \\
\hline 45 & Dodecane & Hydrocarbon & 29.928 & 1200 & 1200 \\
\hline 46 & $\beta$-Cyclocitral & Monoterpene & 30.594 & 1217 & 1217 \\
\hline 47 & Citronellic acid, methyl ester & Ester & 32.691 & 1260 & 1261 \\
\hline 48 & 2,6-Octadienoic acid, 3,7-dimethyl-, methyl ester & Ester & 35.709 & 1323 & 1323 \\
\hline 49 & Sesquiterpene 1 & Sesquiterpene & 35.975 & 1329 & $\mathrm{n} / \mathrm{a}$ \\
\hline 50 & Sesquiterpene 2 & Sesquiterpene & 36.113 & 1331 & $\mathrm{n} / \mathrm{a}$ \\
\hline 51 & $\delta$-Elemene & Sesquiterpene & 36.504 & 1340 & 1339 \\
\hline
\end{tabular}


TABLE 1 | Continued

\begin{tabular}{|c|c|c|c|c|c|}
\hline$\#$ & Analyte & Class & RT (min) & $\mathbf{R} \mathbf{I}_{\text {exp }}$ & $\mathbf{R I}_{\text {Lit }}$ \\
\hline 52 & $\alpha$-Cubebene & Sesquiterpene & 37.048 & 1352 & 1352 \\
\hline 53 & Cyclosativene & Sesquiterpene & 37.761 & 1367 & 1368 \\
\hline 54 & $\alpha$-Ylangene & Sesquiterpene & 38.041 & 1373 & 1373 \\
\hline 55 & $\alpha$-Copaene & Sesquiterpene & 38.353 & 1380 & 1380 \\
\hline 56 & $\beta$-Bourbonene & Sesquiterpene & 38.689 & 1387 & 1388 \\
\hline 57 & Sesquiterpene 3 & Sesquiterpene & 38.903 & 1392 & $\mathrm{n} / \mathrm{a}$ \\
\hline 58 & $\beta$-Elemene & Sesquiterpene & 39.035 & 1395 & 1394 \\
\hline 59 & Sesquiterpene 4 & Sesquiterpene & 39.179 & 1398 & $\mathrm{n} / \mathrm{a}$ \\
\hline 60 & $\alpha$-Gurjenene & Sesquiterpene & 39.796 & 1412 & 1413 \\
\hline 61 & $\beta$-Caryophyllene & Sesquiterpene & 40.339 & 1424 & 1424 \\
\hline 62 & $\gamma$-Elemene & Sesquiterpene & 40.721 & 1433 & 1433 \\
\hline 63 & $\alpha$-Caryophyllene & Sesquiterpene & 41.076 & 1441 & 1443 \\
\hline 64 & Sesquiterpene 5 & Sesquiterpene & 41.225 & 1445 & $\mathrm{n} / \mathrm{a}$ \\
\hline 65 & Sesquiterpene 6 & Sesquiterpene & 41.884 & 1460 & $\mathrm{n} / \mathrm{a}$ \\
\hline 66 & $\gamma$-Muurolene & Sesquiterpene & 42.189 & 1467 & 1465 \\
\hline 67 & $\delta$-Muurolene & Sesquiterpene & 42.274 & 1468 & 1468 \\
\hline 68 & $\alpha$-Muurolene & Sesquiterpene & 43.432 & 1499 & 1498 \\
\hline 69 & Germacrene D & Sesquiterpene & 43.506 & 1496 & 1492 \\
\hline 70 & $\gamma$-Cadinene & Sesquiterpene & 43.929 & 1508 & 1509 \\
\hline 71 & $\sigma$-Cadinene & Sesquiterpene & 44.455 & 1523 & 1523 \\
\hline 72 & $\delta$-Cadinene & Sesquiterpene & 44.819 & 1533 & 1533 \\
\hline 73 & Sesquiterpene 7 & Sesquiterpene & 45.069 & 1540 & $\mathrm{n} / \mathrm{a}$ \\
\hline 74 & Sesquiterpene 8 & Sesquiterpene & 45.21 & 1544 & $\mathrm{n} / \mathrm{a}$ \\
\hline 75 & 3,7(11)-Selinadiene & Sesquiterpene & 45.285 & 1546 & 1545 \\
\hline 76 & Germacrene B & Sesquiterpene & 45.441 & 1551 & 1553 \\
\hline 77 & Sesquiterpene 9 & Sesquiterpene & 46.098 & 1569 & $\mathrm{n} / \mathrm{a}$ \\
\hline 78 & Caryophyllene oxide & Sesquiterpene & 47.063 & 1597 & 1599 \\
\hline 79 & Sesquiterpene 10 & Sesquiterpene & 47.44 & 1609 & $\mathrm{n} / \mathrm{a}$ \\
\hline 80 & Sesquiterpene 11 & Sesquiterpene & 47.668 & 1617 & $\mathrm{n} / \mathrm{a}$ \\
\hline 81 & $\tau$-Cadinol & Sesquiterpene & 48.564 & 1647 & 1643 \\
\hline 82 & $\alpha$-Cadinol & Sesquiterpene & 48.949 & 1660 & 1657 \\
\hline 83 & Sesquiterpene 12 & Sesquiterpene & 50.169 & 1702 & $\mathrm{n} / \mathrm{a}$ \\
\hline 84 & 2,6,10-Dodecatrien-1-ol, 3,7,11-trimethyl-, (E,E) & Sesquiterpene & 50.712 & 1723 & 1722 \\
\hline
\end{tabular}

\section{RESULTS}

\section{Anatomical Analysis}

The leaves of M. splendens in non-galled condition are green (Figure 1A), dorsiventral and hypostomatic. The epidermis is uniseriate, the mesophyll has a 1- layered palisade parenchyma and 7-10 layered spongy parenchyma. Secretory cavities occur all over the mesophyll, and in the midrib cortex (Figure 1B).

The galls are green with the rolling movement of leaf lamina upward, along both sides of the midrib (Figure 1A). Galling thrips in several stages of life occur inside the galls, but parasitoids and predators are rare. Hypersensitive reactive spots form in response to the feeding activity of the thrips in the epidermis and mesophyll (Figure 1C). The number of secretory cavities increases and the cells of the epithelium are hypertrophied (Figure 1D). The spongy parenchyma is 5-7 layered and compact due to a reduction of intercellular spaces. Large air cavities are evident within mesophyll cells (Figure 1E). The oviposition takes place inside leaf tissues, where the larvae develop. Later on, the immature thrips hatch out of the tissues (Figures 2A-D) and start feeding.

\section{Quantitative Analysis of Glands}

Both the number and the area of the oil glands are statistically different between non-galled leaves and galls. The density of the glands per $\mathrm{mm}^{2}$ was higher in galls than in non-galled leaves $(p<0.0001)$ (Figure 3A), and the area of the glands was larger and more variable $(p=0.0227)$ in galls than in non-galled leaves (Figure 3B).

For the quantitative analysis of the oil glands, the ANOVA tests were applied for parametric data, and Kruskal test for non-parametric data.

\section{Volatile Profile Characterization by HS-SPME-GC/MS}

A total of 84 compounds were aligned across all samples. Twelve compounds were tentatively identified only as sesquiterpenes due to their characteristic mass spectra fragmentation pattern, inconsistencies between NIST library hit, experimental retention indexes and literature retention indexes. The complete identification of 72 metabolites was possible according to their retention indexes (Table 1). The 36 sesquiterpenes 


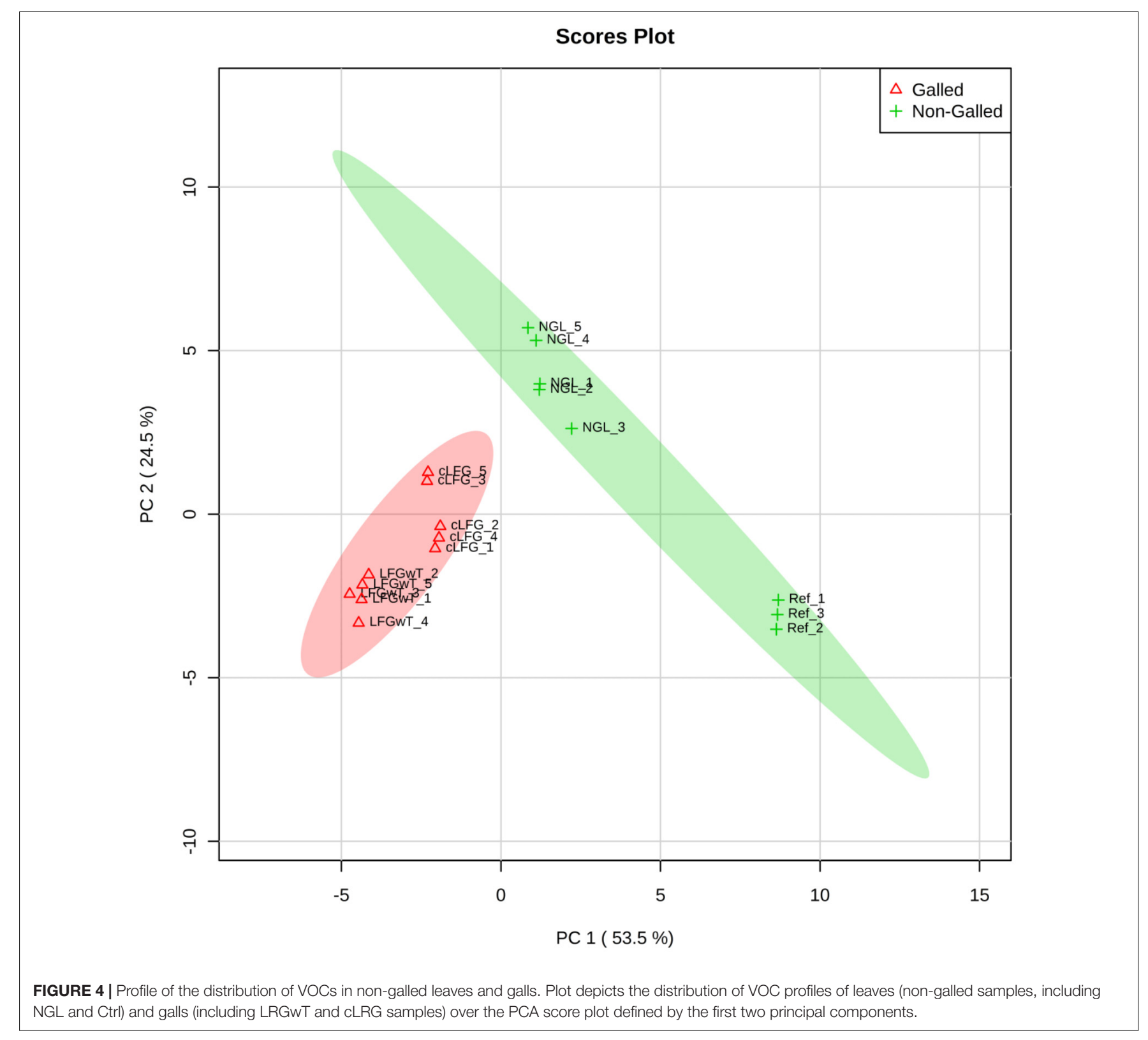

constitute the major class of the identified compounds, followed by monoterpenes (12), alcohols (10), aldehydes (10), esters (5), aromatic compounds (5), ketones (3), and hydrocarbon (1). Green leaf volatiles (GLVs), comprising low molecular weight oxygenated compounds, amounted to 17 compounds.

The profiles of volatile organic compounds (VOC) obtained from the four composites could be separated into two classes by the PCA analysis: (1) leaves of the non-galled individual, comprising the control group (Ctrl) together with the non-galled leaves (NGL), and (2) galls with thrips (LRGwT) and galls without thrips (cLRG) (Figure 4).

Even though the four groups could be successfully separated into two classes (PCs 1 and 2 explain $78 \%$ of variance in the data), the 25 most discriminating VOCs show that there is a clear distinction between the profile of the groups within a class, i.e., between the Ctrl and the NGL samples, and between the cLRG and the LRGwT (Figure 5). The main compounds responsible for the separation of the groups are 2-E-hexenal (\#14), sesquiterpene 5 (\#64), $\beta$-caryophyllene (\#61), and $\beta$-bourborene (\#56) that are upregulated in the leaves of non-galled samples, and methyl salicylate (\#42), 3-Z-hexen-1-ol (\#15), 2-E-hexen-1-ol (\#16) and 1 -hexanol (\#17), which are upregulated in the samples of galls (Figure 6). In fact, there were significant distinguishing features between the control sample (Ctrl) and the non-galled leaves of galled individuals (Figure 7). Contrastingly, to the higher levels of sesquiterpenes in the samples of the control individual, there were increased levels of aldehydes in the non-galled samples of galled individuals, mainly of the C6 aldehydes from GLV class. 


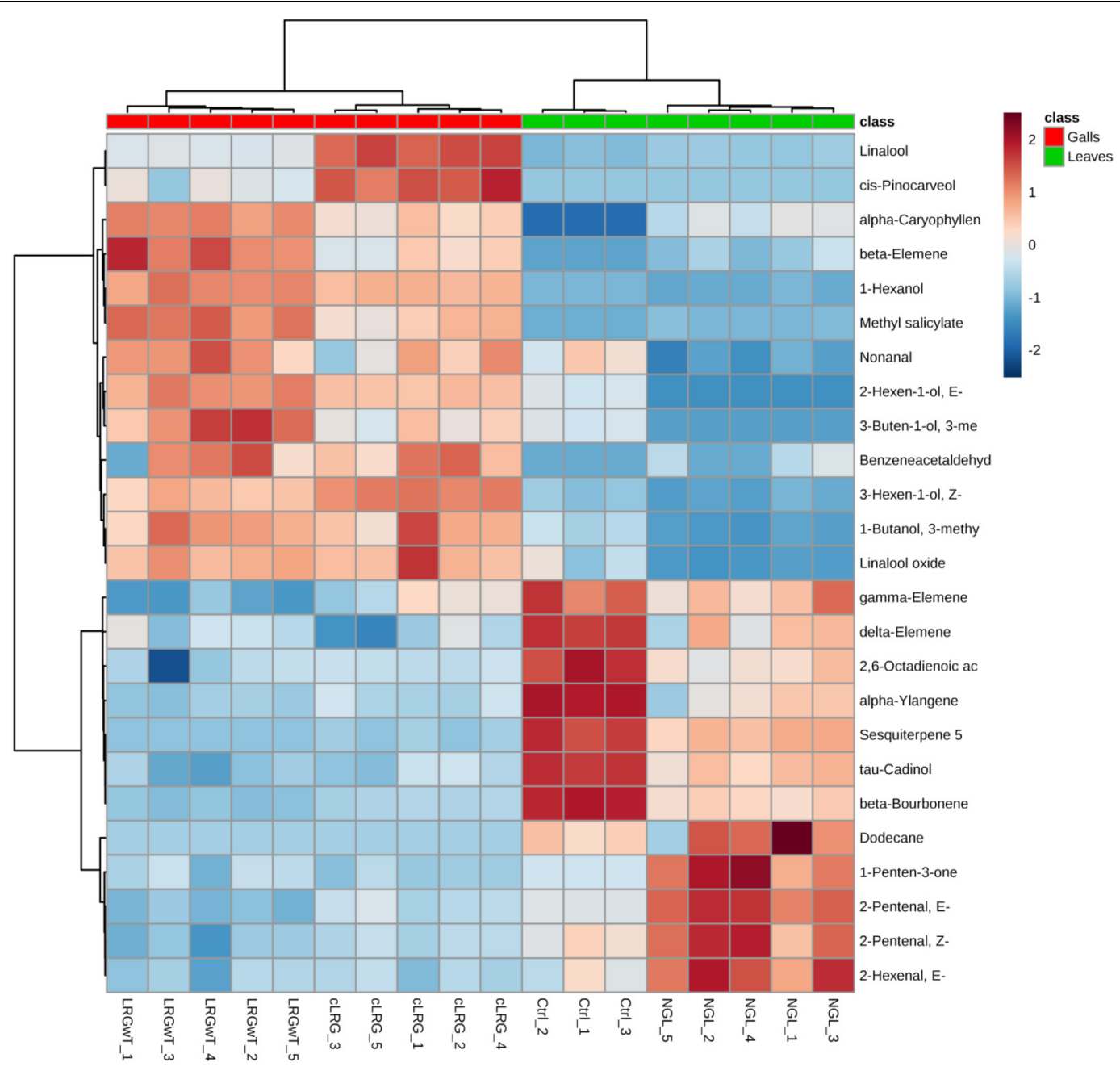

FIGURE 5 | Profile of the distribution of VOCs in non-galled leaves and galls. Plot shows the heat map distribution of the 25 most discriminating VOCs identified by SPME-GC-MS analysis. Color key indicates metabolite expression value, blue: Lowest, red: highest.

In a similar pattern, benzaldehyde (\#21) and methyl salicylate (\#42) appeared to be upregulated in the LRGwT (galls with inducing thrips inside) composite as compared to the cLRG. Moreover, sesquiterpenes, such as $\delta$-muurolene (\#67), $\beta$-elemene (\#58) and $\alpha$-caryophyllene (\#63), decreased in the composites of galls from which the galling Nexothrips were removed (cLRG) (Figure 8).

\section{DISCUSSION}

The first step in current investigation, i.e., the structural profile of non-galled leaves and galls, revealed that the development of the leaf rolling gall morphotype on M. splendens results in discrete alterations in epidermis, and in conspicuous alterations in palisade and spongy parenchymas. These alterations lead to a complete rolling of leaf lamina upward.

The mosaic of tissue alterations of Nexothrips-induced galls on M. splendens with its peculiar air cavities and compactness of spongy parenchyma is not an exclusive feature, for it has been previously described for galls of Aneurothrips priesneri Bhatti on Cordia obliqua Willd. This pattern seems to be consequence of cell displacement due to the stretching and folding/rolling of leaf lamina throughout gall development (Ananthakrishnan and Raman, 1989). Even though the origin of the stimuli for gall induction remains unknown (Mound and Kranz, 1997), the insect saliva seems to be involved in gall induction and development of thrips-induced galls (Ananthakrishnan and Raman, 1989). Nevertheless, the role of oviposition has not been considered in gall induction of most galling Thysanoptera, since females of suborder Tubulifera lay their eggs externally to plant tissues. Comparatively, the ovipositor of most female Terebrantia is well-developed, and eggs are inserted in a cavity within mesophyll cells. Although this endophytic process has been shown by almost all phytophagous Terebrantia, only three thrips species are reported as capable of causing plant cell responses and gall induction through oviposition (Ananthakrishnan, 1978a,b; Tree and Mound, 2009). 

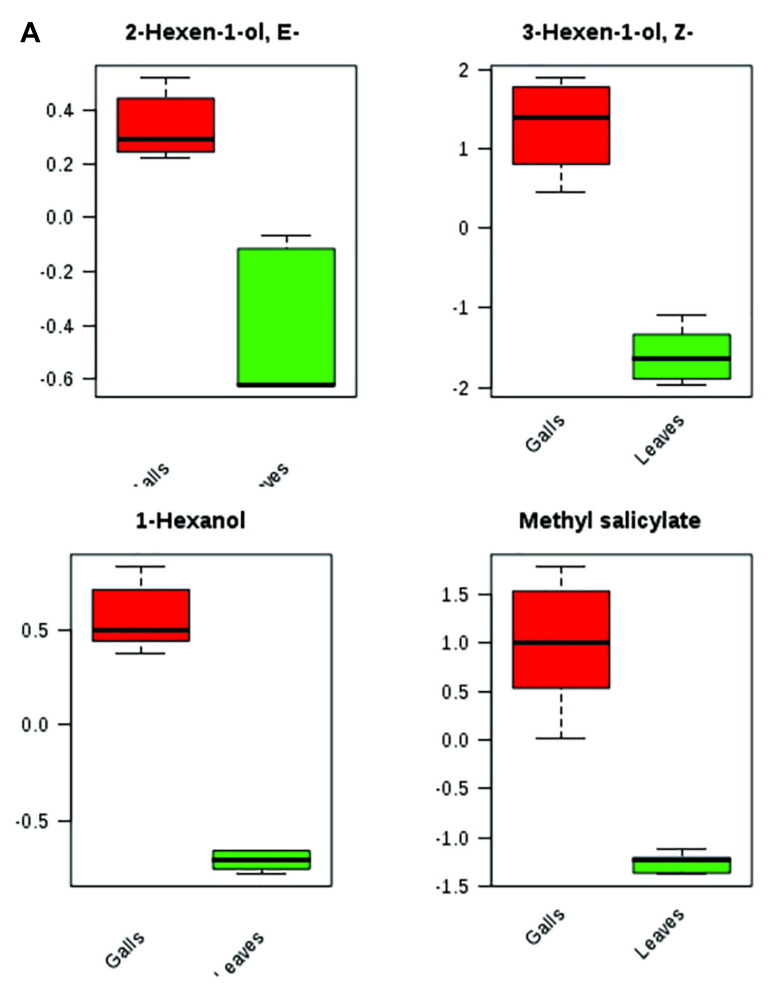

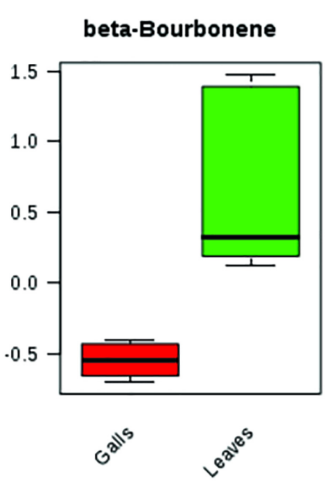

2-Hexenal, E-
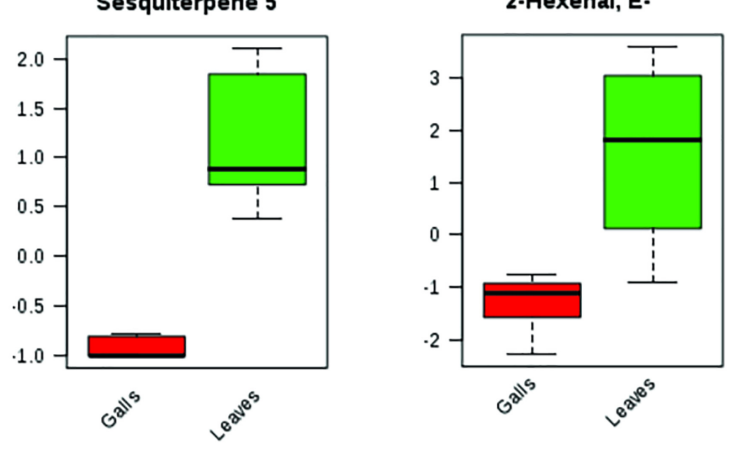

FIGURE 6 | Box plots of top metabolites that significantly differed between leaves and galls. (A) VOCs up regulated in gall samples. (B) VOCs down regulated in gall samples.

The females of Nexothrips oviposit on mature leaves of M. splendens, which should be a strategy to avoid the crushing of the egg cavities by the intense cell proliferation common in young developing leaves (Rivnay, 1935). Besides crushing the cavities, the hyperplasia of young leaf tissues should end up pushing eggs out of the leaf, which should not favor the establishment of the galling thrips and gall development. The ability of inducing galls on mature leaves rather than exclusively on young leaves, as is common for most galling insects, guarantees to the individuals of Nexothrips sp. a high availability of sites for completing their life cycles. However, the more differentiated is a cell, the less responsive it is. So, inducing galls on mature leaves may impose constraints for the differentiation of high-specialized cells, such as those of true nutritive tissues (Ferreira et al., 2017). Nutritive cells may occur in some Thysanoptera galls (Ananthakrishnan and Raman, 1989), but they are absent in the galls induced by Nexothrips studied here. The absence of a true nutritive tissue indicates that the galling Nexothrips should feed on epidermal cell contents. Also, the reduced hypersensitive sites next to the oil glands in the galls on M. splendens indicate that the Nexothrips may access the cells of the oil glands and take advantage of its high energetic content. Taking into consideration the non-occurrence of secretory structures other than the oil glands in leaves of $M$. splendens, we assume their potential for secreting the major portion of the VOCs.

\section{Potential Roles of the Chemical Profile of the Oil Glands}

Currently, the second step of investigation revealed that gall induction and establishment caused alterations in the density and area of the oil glands, which are larger in galls than in the non-galled leaves. The increased size of the oil glands indicates an enhancement in the potential for the production of volatiles in galled condition. Such potential can provide a favorable microenvironment to the galling Nexothrips sp., which can benefit from the products of the glands, as proposed for other galling insect-host plant systems (Stone and Schonrögge, 2003).

\section{Role of Volatiles as Biomarkers and Chemical Signalers}

The volatiles can act by chemical signaling for herbivores, and their biosynthesis can be altered in response to herbivory (Valladares et al., 2002; Banchio et al., 2005), as observed for $M$. splendens regarding the concentration of volatiles. Currently, gall induction alters the size and area of the oil glands, and accordingly the concentration of VOCs in the samples of non-galled leaves and of galls is distinct. The substantial changes in the emissions of volatiles as gall induction consequence is expected (Izzo et al., 2006), and is clearly perceived in the content of sesquiterpenes in 


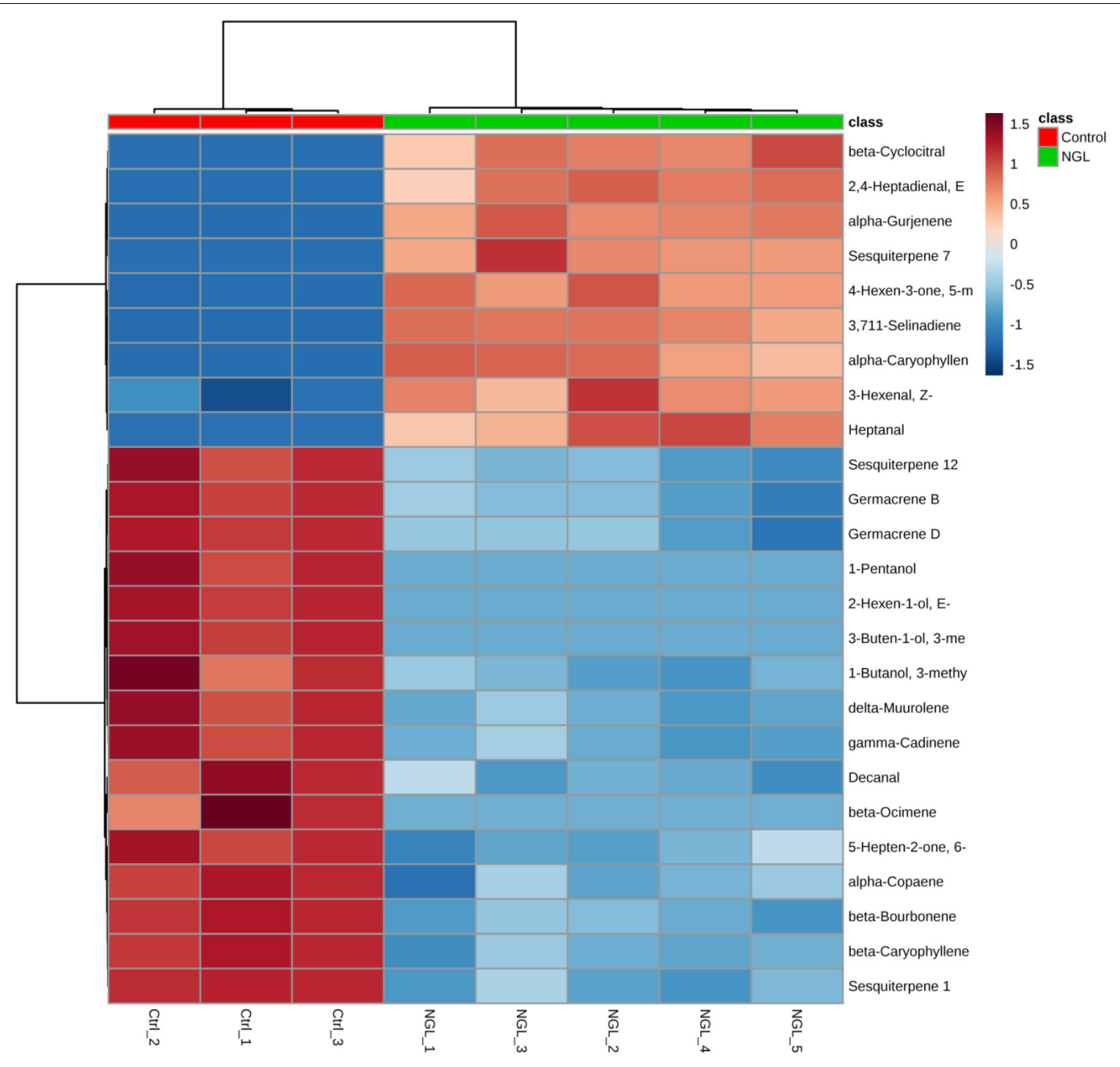

FIGURE 7 | Heat map of non-galled leaves. The heat maps were constructed based on the 25 most discriminating compounds. Compounds identified by HS-SPME-GC/MS. Color key indicates metabolite expression value, blue: Lowest, red: highest.

M. splendens. Such quantitative changes have been reported for other three galling herbivore-host plant systems ( $c f$. Tooker et al., 2002; Tooker and Hanks, 2004, 2006). The volatiles, besides attracting reproductive partners (Koschier et al., 2000, 2007) may act in direct or indirect plant defenses against natural enemies (Dudareva et al., 2004; Koschier et al., 2007; Oates et al., 2016). Due to the high frequency of galls in the population of $M$. splendens along the year, we can infer that the repellent properties of the sesquiterpenes were not effective against the associated galling Nexothrips. The quantitative differences in the content of sesquiterpenes detected by the SPME analysis in Nexothrips sp. galls in comparison to the non-galled condition implied favorable features for the galling Thysanoptera. The volatiles produced in the different samples of $M$. splendens should be related both to insect-plant and to plant-plant interactions.
Chemical signaling, mediated by volatiles, may allow the insects to find and recognize their host plants (Hanula et al., 1985; Tooker and Hanks, 2004), but may also attract natural enemies (James and Chem, 2005). Such inference is based on the ability of the inducers to stimulate host plant responses, which trigger local reactions, and may interfere directly with the insect communication with its host plant (Moura et al., 2009a,b; Oates et al., 2016), but also with other plants in the population. In the population of $M$. splendens at the PESV, there is one plant individual, which has never associated to Nexothrips sp. The lowest content observed in the chemical profile of this individual of $M$. splendens, the aforementioned control individual, and the highest content observed in the general composite of the non-galled leaves (NGL) of the other individuals in the population indicates that the galling activity of Nexothrips sp. may have caused long-distance effects (Mani, 1964) over the population of M. splendens. The secondary effects 


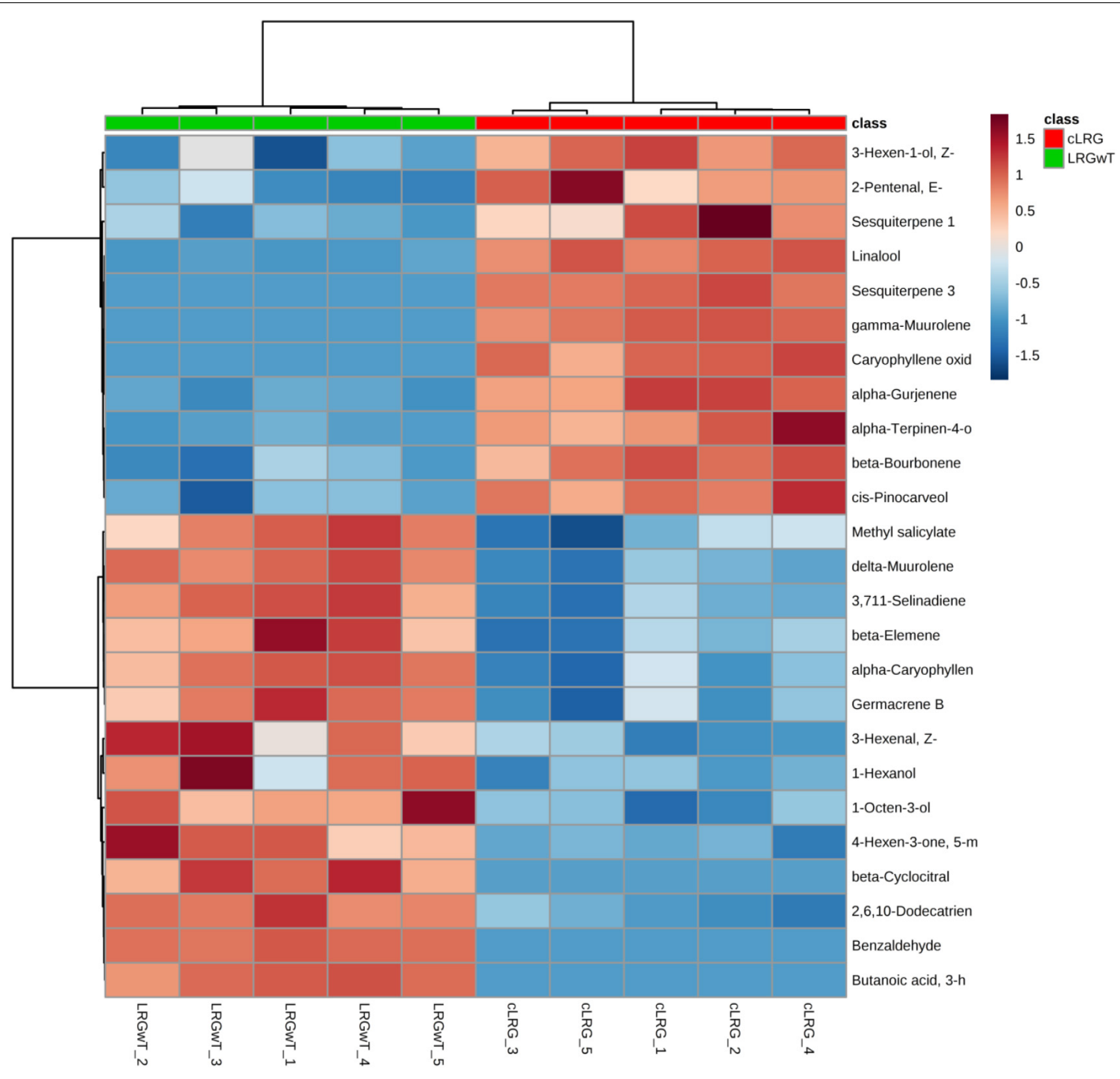

FIGURE 8 | Heat map of galls. The heat maps were constructed based on the 25 most discriminating compounds. Compounds identified by HS-SPME-GC/MS. Color key indicates metabolite expression value, blue: Lowest, red: highest.

or tele-effects were first described for galls induced in roots, but causing changes in flowers of the host plant, Heterodera marioni (Mani, 1964), and has recently been reported for Ditylenchus gallaeformans galls on Miconia spp (Ferreira et al., 2017).

The effect of gall induction on other host plant organs, by the production of secondary metabolites, including volatile compounds, may represent an indirect defense of the plant (Unsicker et al., 2009; Fürstenberg-Hägg et al., 2013; Oates et al., 2016). Despite of their simple molecular structures, the alcohols and aldehydes deriving from the lypoxygenase (LOX) pathway, methyl salicylate, and 3-hexenyl butanoate of low molecular weight pertaining to the GLV class were detected in the samples of Nexothrips sp. galls on M. splendens, and can act as signaling molecules in plantherbivore interactions (Yan and Wang, 2006; Damasceno et al., 2010). The chemical signaling between M. splendens and its associated galling herbivores may be mediated by some of the terpenes detected in samples of galled leaves.
The monoterpenes (geraniol) and the sesquiterpenes may play an attractive role for the adult female of Nexothrips sp., as proposed for Frankliniella occidentalis, a generalist phytophagous species found worldwide (Koschier et al., 2000, 2007). The geraniol and sesquiterpenes-mediated attraction is yet to be tested for the four galling herbivores reported on M. splendens on PESV (Portugal-Santana and Isaias, 2014). The decreasing concentration of $\delta$-muurolene (\#67), $\beta$-elemene (\#58) and $\alpha$-caryophyllene (\#63) in the samples from which the galling thrips were removed (cLRG) could be an indicative that the individuals of Nexothrips sp. were manipulating M. splendens metabolism and assimilating some of these secondary metabolites.

The detection of methyl salicylate $(\# 42)$ in the samples of galls had also been related to acquired resistance and indirect plant defense (Oates et al., 2016). Methyl salicylate is a plant semiochemical related to stress signaling (Pickett et al., 2006), and it is generally 
described as anti-herbivoric, attractive to beneficial insects that would kill herbivores (Bruinsma et al., 2009), and as a pheromone (James and Price, 2004; Troncoso et al., 2012). In M. splendens, the production of methyl salicylate neither affected the life cycle of the inducing thrips nor attracted natural enemies, since individuals in several stages of life occurred inside the galls, and the rate of hyperparasitism was apparently low in comparison to other Neotropical systems (Gonçalves et al., 2009; Carneiro et al., 2013). Such inability of methyl salicylate as an anti-herbivore substance may be effect of its low concentration and consequently its limited potential to stimulate the galling thrips responses, crucial for attractiveness or repellency (Koschier et al., 2000, 2002; Bruhin, 2009).

\section{CONCLUSION}

The rare event of gall induction by the Terebrantia studied here revealed mesophyll compactness and formation of air cavities as new features, first described for the Neotropical Thysanoptera-induced galls. The structural profile of $M$. splendens non-galled leaves and galls revealed that the main alteration regards the number and size of the oil glands. As the only secretory structure differentiated in leaves of $M$. splendens, the oil glands should be the main secretory sites responsible for the peculiar chemical profile of the analyzed samples. The main alteration in GLVs concentration in response to Nexothrips sp. activity indicates the GLVs as possible stress biomarkers involved in the host plant-galling Thysanoptera signaling. Moreover, the methyl salicylate in the composite of the non-galled individual reveals a potential plant resistance stimulated as a long-distance effect. In addition to the signaling effects of the volatile compounds produced by the non-galled leaves and the galls on M. splendens, it can be hypothesized that the individuals of the galling Nexothrips sp. may have captured, incorporated, and metabolized some of these VOCs. This hypothesis is based on the increased levels of some sesquiterpenes detected in the composites containing the galling thrips in comparison to the composites without thrips.

\section{REFERENCES}

Adams, R. P. (2001). Identification of Essential Oil Components by Gas Chromatography/Quadrupole Mass Spectroscopy. Carol Stream, IL: Allured Publishing Corporation, 804.

Adams, R. P. (2007). Identification of Essential Oil Components by Gas Chromatography/Mass Spectroscopy, 4th Edn. Carol Stream, IL: Allured Publishing Corporation.

Ananthakrishnan, T. N. (1978a). On some aspects of thrips galls. Bull. Soc. Bot. France. Actual. Bot. 127, 31-34. doi: 10.3897/BDJ.2.e1077

Ananthakrishnan, T. N. (1978b). Thrips Galls and Gall Thrips. Technical Monograph of the Zoological Survey of India. Delhi: Controller of Publications, $1-69$.

Ananthakrishnan, T. N., and Raman, A. (1989). "Morphology of galls," in Thrips and Gall Dynamics, eds T. N. Ananthakrishnan and A. Raman (New Delhi: Oxford and IBH Publishing), 67-73.

Banchio, E., Zygadlo, J., and Valladares, G. R. (2005). Effects of mechanical wounding on essential oil composition and emission of volatiles from

\section{AUTHOR CONTRIBUTIONS}

NJ and DA did the field sampling. ÉS-S, GS, GLS, and CZ did the chemical analyses. NJ, DA, and RI analyzed the structure. AC did the characterization and ecology of thrips. NJ, ÉS-S, DA, GS, GLS, CZ, AC, and RI analyzed the data and wrote the manuscript.

\section{FUNDING}

This work was financially supported by Programa de Pós Graduação em Biologia Vegetal da Universidade Federal de Minas Gerais (PPGBV-UFMG).

\section{ACKNOWLEDGMENTS}

The authors thank the Fundação de Apoio à Pesquisa do Estado de Minas Gerais - FAPEMIG, Coordenação de Aperfeiçoamento de Pessoal de Nível Superior - CAPES, and Conselho Nacional de Desenvolvimento Científico e Tecnológico - CNPq (Project BJT 401581/2014-4) for financial support. CZ, GLS, and RI also thank CNPq for fellowships (306067/2016-1, 312247/2016-8, and 307011/2015-1). The Center of Microscopy at the Universidade Federal de Minas Gerais (http://www. microscopia.ufmg.br) provided the equipment and technical support for experiments involving electron microscopy. Dr. Mariana Bunger identified $M$. splendens in the field, and the professionals of State Park Serra Verde supported field campaigns.

\section{SUPPLEMENTARY MATERIAL}

The Supplementary Material for this article can be found online at: https://www.frontiersin.org/articles/10.3389/fpls.2018.01521/ full\#supplementary-material

DATA SHEET S1 | Area value of each compound identified in Myrcia splendens samples by HS-SPME-GC/MS.

Minthostachys mollis. J. Chem. Ecol. 31, 719-727. doi: 10.1007/s10886-0053540-1

Bedetti, C. S., Modolo, L. V., and Isaias, R. M. S. (2014). The role of phenolics in the control of auxin in galls of Piptadenia gonoacantha (Mart.) MacBr (Fabaceae: Mimosoideae). Biochem. Syst. Ecol. 55, 53-59. doi: 10.1016/j.bse.2014.02.016

Bersier, J. D., and Bocquet, G. (1960). "Les methods d'éclaircissement de vascularisation et en morphogénie végétales compares," in Manual Básico de Métodos em Morfologia Vegetal, ed. J. E. Kraus (Seropédica: Editora da Universidade Federal Rural do Rio de Janeiropp), 555-566.

Bragança, G. P., Oliveira, D. C., and Isaias, R. M. S. (2017). Compartmentalization of metabolites and enzymatic mediation in nutritive cells of Cecidomyiidae galls on Piper arboreum Aubl. (Piperaceae). J. Plant Stud. 6, 11-22. doi: 10.5539/jps. v6n $1 \mathrm{p} 11$

Bruhin, D. (2009). Direct and Indirect Effects of Methyl Salicylate and Methyl Jasmonate on Frankliniella Occidentalis Pergande on pot Chrysanthemum. Master thesis: University of Applied Life Sciences and Natural Resources, Vienna. 
Bruinsma, M., Posthumus, M. A., Mumm, R., Mueller, M. J., Van Loon, J. J. A., and Dicke, M. (2009). Jasmonic acid-induced volatiles of Brassica oleracea attract parasitoids: effects of time and dose, and comparison with induction by herbivores. J. Exp. Bot. 60, 2575-2587. doi: 10.1093/jxb/ erp101

Bukatsch, F. (1972). Bermerkungenzur doppelfärbung astrablau-safranin. Mikrokosmos 61, 225-255.

Carneiro, R. G. S., Burckhardt, D., and Isaias, R. M. S. (2013). Biology and systematics of gall-inducing triozids (Hemiptera: Psylloidea) associated with Psidium spp. (Myrtaceae). Zootaxa 360, 129-146.

Carneiro, R. G. S., Castro, A. C., and Isaias, R. M. S. (2014). Unique histochemical gradients in a photosynthesis-deficient plant gall. S. Afr. J. Bot. 92, 97-104. doi: 10.1016/j.sajb.2014.02.011

Cole, R. A., Haber, W. A., and Setzer, W. N. (2008). The leaf oil composition of myrciasplendens from monteverdi, Costa Rica. J. Essent. Oil-Bearing Plants 1, 41-44. doi: 10.1080/0972060X.2008.10643595

Damasceno, F. C., Nicolli, K. P., Caramão, E. B., Soares, G. L. G., and Zini, C. A. (2010). Changes in the volatile organic profile of Schinus polygamus (Anacardiaceae) and Baccharis spicata (Asteraceae) induced by galling psyllids. J. Braz. Chem. Soc. 21, 556-563. doi: 10.1590/S0103-50532010000300023

Dicke, M., Bruin, J., and Sabelis, M. W. (1993). Herbivore-Induced Plant Volatiles Mediate Plant-Carnivore, Plant-Herbivore and Plant-Plant Interactions: Talking Plant Revisited. Rockville: American Society of Plant Physiologists.

Dudareva, N., Pichersky, E., and Gershenzon, J. (2004). Biochemistry of plant volatiles. Plant Physiol. 135, 1893-1902. doi: 10.1104/pp.104.049981

Ferreira, B. G., Álvarez, R., Avritzer, S. C., and Isaias, R. M. S. (2017). Revisiting the histological patterns of storage tissues: beyond the limits of gall-inducing taxa. Botany 95, 173-184. doi: 10.1139/cjb-2016-0189

Fürstenberg-Hägg, J., Zagrobelny, M., and Bak, S. (2013). Plant defense against insect herbivores. Int. J. Mol. Sci. 14, 10242-10297. doi: 10.3390/ijms140510242

Gonçalves, S. J. M., Moreira, G. R. P., and Isaias, R. M. S. (2009). A unique seasonal cycle in a leaf gall inducing insect, the formation of stem galls for dormancy. J. Nat. Hist. 43, 843-854. doi: 10.1080/0022293080261 5690

Guedes, L. M., Aguilera, N., Becerra, J., Hernández, V., and Isasias, R. M. S. (2016). Leaf and stem galls of Schinus polygamous (Cav.) cabr (Anacardiaceae): Anatomical and chemical implication. Biochem. Syst. Ecol. 69, 266-273. doi: $10.1016 /$ j.bse.2016.10.012

Hanula, J. L., Berisford, C. W., and Debarr, G. L. (1985). Monoterpene oviposition stimulants of Dioryctria amatella in volatiles from fusiform rust galls and second-year loblolly pine cones. J. Chem. Ecol. 11, 943-952. doi: 10.1007/ BF01012080

Hori, K. (1992). "Insect secretion and their effect on plant growth, with special reference to hemipterans," in Biology of Insect-Induced Galls, eds J. D. Shorthouse, and O. Rohfristsch (New York: Oxford University Press), 157-170.

Isaias, R. M. S., Carneiro, R. G. S., Oliveira, D. C., and Santos, J. C. (2013). Illustrated and annotated checklist of Brazilian gall morphotypes. Neotrop. Entomol. 42, 230-239. doi: 10.1007/s13744-013-0115-117

Isaias, R. M. S., Oliveira, D. C., Moreira, A. S. F. P., Soares, G. L. G., and Carneiro, R. G. S. (2015). The imbalance of redox homeostasis in arthropodinduced plant galls: mechanisms of stress generation and dissipation. Biochim. Biophys. Acta 1850, 1509-1517. doi: 10.1016/j.bbagen.2015.03.007

Izzo, T. J., Julião, G. R., Almada, E. D., and Fernandes, G. W. (2006). Hiding from defenders: localized chemical modification on the leaves of an amazonian antplant induced by a gall-making insect (Diptera: Cecidomyiidae). Sociobiology $48,417-426$.

James, D. G., and Chem, J. (2005). Further field evaluation of synthetic herbivoreinduced plan volatiles as attractansts for beneficial insects. J. Chem. Ecol. 31, 481-495. doi: 10.1007/s10886-005-2020-y

James, D. G., and Price, T. S. (2004). Field-testing of methyl salicylate for recruitment and retention of beneficial insects in grapes and hops. J. Chem. Ecol. 30, 1595-1610. doi: 10.1023/B:JOEC.0000042072.18151.6f

Johansen, D. A. (1940). Plant micro technique. New York, NY: McGraw-Hill Book Company Inc.

Koschier, E. H., De Kogel, W. J., and Visser, J. H. (2000). Assessing the attractiveness of volatile plant compounds to western flower thrips Frankliniella occidentalis. J. Chem. Ecol. 26, 2643-2655. doi: 10.1023/A:102647012 2171
Koschier, E. H., Hoffmann, D., and Riefler, J. (2007). Influence of salicylaldehyde and methyl salicylate on post-landing behaviour of Frankliniella occidentalis pergande. J. Appl. Entomol. 131, 362-367. doi: 10.1111/j.1439-0418.2007. 01191.x

Koschier, E. H., Sedy, K. A., and Novak, J. (2002). Influence of plant volatiles on feeding damage caused by onion thrips Thrips tabaci. Crop Prot. 21, 419-425. doi: 10.1016/S0261-2194(01)00124-7

Kraus, J. E., and Arduin, M. (1997). Manual Básico de Métodos em Morfologia Vegetal. Seropédica: Federal Rural do Rio de Janeiro.

Mani, M. S. (1964). Ecology of Plant Galls. Heidelberg: Springer. doi: 10.1007/97894-017-6230-4

Meyer, J. (1987). Plant Galls and Gall Inducers. Stuttgart: Gebrüder Borntraeger.

Mound, L. A., and Kranz, B. (1997). "Thysanoptera and plant galls: towards a research programme," in Ecology and Evolution of Plant-feeding Insects in Natural and man-made Environments. National Institute of Ecology, New Delhi, ed. A. Raman (Leiden: Backhuys Publishers), 11-24.

Moura, M. Z. D., Alves, T. M. A., Soares, G. L. G., and Isaias, R. M. S. (2009a). Intra-specific phenotypic variations in Lantana camara leaves affect host selection by the gall maker Aceria lantanae. Biochem. Syst. Ecol. 37, 547-548.

Moura, M. Z. D., Soares, G. L. G., and Isaias, R. M. S. (2009b). Ontogênese da folha e das galhas induzidas por Aceria lantanae Cook (Acarina: Eriophyidae) em Lantana camara L. (Verbenaceae). Rev. Bras. de Bot. 32, 271-282. doi: 10.1590/S0100-84042009000200007

Nakamura, M. J., Monteiro, S. S., Bizarri, C. H. B., Siani, A. C., and Ramos, M. F. S. (2010). Essential oils of four myrtaceae species from the brazilian southeast. Biochem. Syst. Ecol. 38, 1170-1175. doi: 10.1016/j.bse.2010.11.003

Oates, C. N., Denby, K. J., Myburg, A. A., Slippers, B., and Naidoo, S. (2016). Insect gallers and their plant hosts: from omics data to systems biology. Int. J. Mol. Sci. 17, 1891-1905. doi: 10.3390/ijms17111891

O’Brien, T. P., and McCully, M. E. (1981). The Study of Plant Structure: Principles and Selected Methods. Melbourne: Termarcarphy Pty.

Oliveira, D. C., Christiano, J. C. S., Soares, G. L. G., and Isaias, R. M. S. (2006). Reações de defesas químicas e estruturais de Lonchocarpus muehlbergianus Hassl. (Fabaceae) à ação do galhador Euphalerus ostreoides Crawf. (Hemiptera: Psyllidae). Rev. Bras. de Bot. 29, 657-667. doi: 10.1590/S0100-84042006000 400015

Paiva, J. G. A., Fank-De-Carvalho, S. M., Magalhães, M. P., and GracianoRibeiro, D. (2006). Verniz vitral incolor 500 ${ }^{\circledR}$ : uma alternativa de meio de montagem economicamente viável. Acta Bot. Bras. 20, 257-264. doi: 10.1590/ s0102-33062006000200002

Pickett, J. A., Bruce, T. J. A., Chamberlain, K., Hassanali, A., Khan, Z. R., Matthers, M. C., et al. (2006). "Plant volatiles yielding new ways to exploit plant defence," in Chemical Ecology: From Gene to Ecosystem, eds M. Dicke and W. Takken (Berlin: Springer), 161-173.

Portugal-Santana, A., and Isaias, R. M. S. (2014). Galling insects are bioindicators of environmental quality in a conservation unit. Acta Bot. Bras. 28, 594-608. doi: 10.1590/0102-33062014abb3510

Raman, A. (2007). Insect-induced plant galls of India: unresolved questions. Curr. Sci. 92, 748-757.

Raman, A., Schaefer, C. W., and Withers, T. M. (2005). Biology, Ecology, and Evolution of Gall-Inducing Arthropods. Hauppauge, NY: Science Publishers Inc.

Rivnay, E. (1935). Ecological studies of the greenhouse thrips, Heliothrips haemorrhoidalis, in Palestine. Bull. Entomol. Res. 26, 267-278. doi: 10.1603/ EN09058

Rosenthal, G. A., and Berenbaum, M. R. (1992). Herbivores their Interactions with Secondary Plant Metabolites, Vol. 2, 2nd Edn. San Diego, CA: Academic Press Inc.

Shorthouse, J. D., Wool, D., and Raman, A. (2005). Gall-inducing insects-nature's most sophisticated herbivores. Basic Appl. Ecol. 6, 407-411. doi: 10.1016/j.baae. 2005.07.001

Souza Silva, É. A., Saboia, G., Jorge, N. C., Hoffmann, C., Isaias, R. M. d. S., Soares, G. L. G., et al. (2017). Development of a HS-SPME-GC/MS protocol assisted by chemometric tools to study herbivore-induced volatiles in Myrcia splendens. Talanta 175, 9-20. doi: 10.1016/j.talanta.2017.06.063

Stone, G. N., and Schonrögge, K. (2003). The adaptive significance of insect gall morphology. Trends Ecol. Evol. 18, 512-522. doi: 10.1111/j.1558-5646.1998. tb02248.x 
Tooker, J. F., and Hanks, L. M. (2004). Stereochemistry of host plant monoterpenes as mate location cues for the gall wasp Antistrophus rufus. J. Chem. Ecol. 30, 473-477. doi: 10.1023/B:JOEC.0000017995.83676.c9

Tooker, J. F., and Hanks, L. M. (2006). Tritrophic interactions and reproductive fitness of the prairie perennial Silphium laciniatum Gillette (Asteraceae). Environ. Entomol. 35, 537-545. doi: 10.1603/0046-225X-35.2.537

Tooker, J. F., Koenig, W. A., and Hanks, L. M. (2002). Altered host plant volatiles are proxies for sex pheromones in the gall wasp Antistrophus rufus. Proc. Natl. Acad. Sci. 99, 15486-15491. doi: 10.1073/pnas.252626799

Tree, D. J., and Mound, L. A. (2009). Gall-induction by an Australian insect of the family Thripidae (Thysanoptera: Terebrantia). J. Nat. Hist. 43, 1147-1158. doi: 10.1080/00222930902807767

Troncoso, C., Becerra, J., Perez, C., Hernandez, V., Martin, A. S., SanchezOlate, M., et al. (2012). Induction of defensive responses in Eucalyptus globulus (Labill) plants, against Ctenarytaina eucalypti (Maskell) (Hemiptera: Psyllidae). Am. J. Plant Sci. 3, 589-595. doi: 10.4236/ajps.2012.35071

Unsicker, S. B., Kunert, G., and Gershenzon, J. (2009). Protective perfumes: the role of vegetative volatiles in plant defense against herbivores. Curr. Opin. Plant Biol. 12, 479-485. doi: 10.1016/j.pbi.2009.04.001
Valladares, G. R., Zapata, A., Zygadlo, J., and Banchio, E. J. (2002). Phytochemical induction by herbivores could affect quality of essential oils from aromatic plants. J. Agric. Food Chem. 50, 4059-4061. doi: 10.1021/jf011 $608+$

Yan, Z.-G., and Wang, C.-Z. (2006). Wound-induced green leaf volatiles cause the release of acetylated derivatives and a terpenoid in maize. Phytochemistry 67, 34-42. doi: 10.1016/j.phytochem.2005.10.005

Conflict of Interest Statement: The authors declare that the research was conducted in the absence of any commercial or financial relationships that could be construed as a potential conflict of interest.

Copyright (c) 2018 Jorge, Souza-Silva, Alvarenga, Saboia, Soares, Zini, Cavalleri and Isaias. This is an open-access article distributed under the terms of the Creative Commons Attribution License (CC BY). The use, distribution or reproduction in other forums is permitted, provided the original author(s) and the copyright owner(s) are credited and that the original publication in this journal is cited, in accordance with accepted academic practice. No use, distribution or reproduction is permitted which does not comply with these terms. 